RESEARCH PAPER

\title{
Going below the line: creating transportable brands for Australia's dark market
}

\section{S M Carter}

Correspondence to: Stacy M Carter, School of Public Health, Room 128A Building A27, University of Sydney NSW 2006, Australia; carters@ health.usyd.edu.au
Objective: To investigate non-point-of-sale cigarette marketing in Australia, one of the "darkest" markets in the world.

Design: Analysis of 172 tobacco industry documents.

Results: The tobacco industry has continued to market their products despite severe restrictions on legal marketing activity. They made careful plans to circumvent regulation well in advance. In preparation for bans, they chose and strengthened existing brands to enable their continued success in a dark market and prepared the consumer for bans by increasing their spending on below the line activities. Bans reduced the industry's effectiveness and efficiency. After bans new brand launches stopped: instead key existing brands were strengthened via alterations to the product, line extensions, and stretching loopholes in the legislation as far as possible. In line with the general trend towards integrated marketing, a range of activities have been used in combination, including guerrilla marketing, advertising in imported international magazines, altering the pack, sponsorships, brand stretching, event promotions, lifestyle premiums, and the development of corporate websites.

Conclusions: The tobacco industry acknowledges that marketing restrictions have an impact, validating their continued use in tobacco control. The industry is extremely creative in circumventing these marketing restrictions, requiring tobacco marketing regulations to be informed by marketing expertise, regularly updated, and to adopt the broadest possible scope. Tobacco control advocates, particularly those communicating with young people, could learn from the creativity of the tobacco industry.
$\mathrm{T}$ his paper discusses the marketing strategies, other than point-of-sale (POS) marketing, used by the tobacco industry in Australia. The retail environment is extremely important in Australia's dark market, and is neglected here only because it is the focus of another paper in this supplement. ${ }^{1}$ A third relevant paper in this supplement discusses the three brand categories operating in Australiapremium, mainstream, and supervalue. ${ }^{2}$ The significance of the cigarette pack as a marketing tool has already been explored in the literature. ${ }^{34}$

Australia is a highly restricted marketing environment for tobacco-what the tobacco industry refers to as a "dark market". Federal Australian law has made most forms of tobacco marketing illegal, starting in 1976 and reaching a watershed in the (Federal) Tobacco Advertising Prohibition (TAP) Act 1992.5 On a background of existing television, radio and cinema bans, the TAP Act prohibited print advertising, domestic sponsorships and out-of-home $(\mathrm{OOH})$, with some notable exceptions, particularly "internationally significant" sponsorships, which cease in 2006.

\section{Good marketing integrates above-the-line and below- the-line strategies}

There are two kinds of marketing strategies that can be used to promote any product: "above-the-line" (ATL, essentially advertising in the mass media) and "below-the-line" (BTL). These category names reflect the business practices of advertising agencies. Agencies generally make commission on placement of advertisements in newspapers, magazines and cinema, and on television, radio and billboards, ${ }^{6}$ a fee that appears "above the line" on their bill. ${ }^{7}$ Traditionally, other forms of promotion-events, POS displays, direct marketing, email promotions, text message promotions, premiums, price reductions, public relations activities, sponsorship, trade shows, exhibitions, sales literature and catalogues-were charged at a fixed fee and thus appeared "below the line". ${ }^{6-12}$

Traditionally ATL and BTL strategies have been considered distinct, and BTL the poor cousin. In fact, some agencies have argued that BTL cheapens a brand and undermines long term brand prospects. ${ }^{6}$ However, increasingly, BTL strategies are recognised as economical, unique, and personal ways to achieve "cut-through" in the supersaturated advertising environment. Some marketing theorists and practitioners now argue that ATL is relatively unsophisticated and poor value, particularly for young, cynical, media-savvy markets. The key to powerful marketing, and standard marketing practice, is now the "integration" of a range of complementary ATL and/or BTL strategies to provide multifaceted support for a brand. ${ }^{13} 14$

\section{The tobacco industry: a special kind of integrated marketing}

This general shift in marketing away from the presumed superiority of ATL and towards integration and the power of BTL has special significance for the tobacco industry. Australian tobacco marketers are expert at integrated and BTL marketing. However, as they acknowledge, they have developed these skills not to keep up with other industries, but because the Australian tobacco market is among the darkest in the world..$^{16}$ Because of progressive regulation, the Australian cigarette industry has been forced into dependence on creative BTL strategies alone to formulate an integrated marketing mix.

Abbreviations: ATL, "above-the- line"; BTL, "below-the-line"; $\mathrm{OOH}$, out-of-home; PML, Philip Morris (Australia) Limited; POS, point-of sale; TAP Act, Tobacco Advertising Prohibition Act 
The new BTL: guerrilla marketing

Since the late 1990s, for all kinds of products but particularly those for youth markets, BTL has included "buzz", "viral" or "guerrilla" marketing, which is intended to create a word-ofmouth "buzz" and thus spread like a "virus". It is characterised by subversion of the transparency of commercial messages to make a consumer think that they are discovering something for themselves (thus "guerrilla") —a phenomenon which is also central to coercions such as pyramid selling and cult recruitment. ${ }^{17}$ Guerrilla marketers may, for example, pay teens to talk to their friends about a product, commission footpath graffiti, or create an event or a website which, rather than containing overt brand imagery, is consistent with the image of the product and "coincidentally" contains it, without overtly delivering a selling message.

Guerrilla event marketing for tobacco is well developed and documented in Australia. There are many examples. A leading fashion designers' after-show-party, bankrolled by a cigarette manufacturer, featured cigarette-bearing models. ${ }^{18}$ A 1950s themed room in a club was visited, with much fanfare, by young models who stacked a strategically placed retro refrigerator with cigarettes. * A dance party featuring a wide range of "feminine" products, including cigarettes, was promoted via the street press and followed up with questionnaires to partygoers about their smoking. Philip Morris (Australia) Limited (PML) has pleaded guilty to the charge that the latter event was cigarette advertising. ${ }^{19} 20$ Importantly, the people attending these events did not expect cigarettes to be featured, and in some instances co-sponsors claimed not to know that tobacco money was involved.

\section{METHODS}

Data came from primary and secondary document sites on the world wide web arising from litigation in the USA. ${ }^{21}$ Documents came from the primary sites of the manufacturers, ${ }^{22}$ the Council for Tobacco Research, ${ }^{23}$ and the US Tobacco Institute ${ }^{24}$ and the secondary sites of Tobacco Documents Online (Bliley, BC, Health Canada and Guildford Miscellaneous collections), ${ }^{25}$ the Canadian Council for Tobacco Control site, ${ }^{26}$ the British Columbia Ministry of Health Services site, ${ }^{27}$ and the Center for Disease Control and Prevention Guildford site. ${ }^{28}$ The search string (pagewood or moorabbin or granville or australia or sydney or melbourne or brisbane or hobart or adelaide or perth or canberra or amatil or wills) has been used throughout the project to gather documents relating to the Australian market. Six hundred and ninety two of these were relevant to cigarette branding in Australia, and of these 172 dealt specifically with issues of transportability of brands and the importance of retailers. This paper presents only a subset of the evidence: all 172 documents are available from http:// tobacco.health.usyd.edu.au/site/gateway/docs/search.htm. An overview of our approach to document searching and analysis is available elsewhere. ${ }^{29}$ The three main trade journalsAustralian Retail Tobacconist, Retail World, and Australian Service Station and Convenience Store News (pre November 2001)/ Australian Convenience Store News (post November 2001) were also searched by hand (volumes from 1990 to the present) for information on the industry's marketing strategies.

\section{RESULTS}

Resilience, substance, transportability: keys to a dark market cigarette brand

In 1990, before the introduction of the TAP Act, PML launched a new (unsuccessful) brand, Belmont, to compete with

*Personal communication from Fiona Cameron, freelance journalist, Melbourne, 19 July 2002.

\section{Glossary of terms}

- Above the line (ATL): marketing via the mass media (print, television, radio, posters/billboards and cinema)

- Below the line (BTL): marketing via methods other than mass media

- Brand stretching: promoting a cigarette brand via the marketing of non-tobacco products under the same brand

- Cut-through: getting noticed by the consumer above the "noise" of the crowded marketing environment

- Dark market: highly restricted marketing environment

- Guerilla, buzz or viral marketing: marketing which appears not to be an advertisement, but rather creates an environment (for example, street graffiti, parties, websites, conversations with peers) consistent with a brand's identity, in which the brand "coincidentally" appears

- Out-of-home (OOH): billboards, or outdoor advertising

- Point of sale marketing (POS): the arrangement of product and placement of promotional material in retail stores

- Premiums: gifts, usually with purchase (for example, buy two packs, get a free lighter)

- Text message promotions: promotions via text-message (SMS) on mobile (cellular) phones, a very popular form of communication in Australia, particularly among young people

Rothmans' Winfield, and "to ensure a balanced aggressive portfolio entering the print ban era". ${ }^{30}$ Belmont's launch plan was classic integrated marketing, combining $\mathrm{OOH}$, press inserts, POS, distribution, aggressive direct marketing by mail to Winfield smokers, and premiums in convenience retail outlets as incentives for both retailers and customers. Thirty hostesses in hotels and clubs offered samples and trade-ups (a free pack of Belmont cigarettes for smokers in exchange for the pack of competitor brand being smoked), playing "a critical role within the tactical mix in gaining trial amongst targeted opposition smokers, building awareness and creating word of mouth communication". ${ }^{30}$

In 2003, 11 years after the introduction of the TAP Act, marketing, in an evolved form, retains its central place. Indeed readers of British American Tobacco Australia's 2000 annual report could be forgiven for thinking the TAP Act was never passed. A typical sample: “Dunhill's presence as the leading super-premium brand was enhanced by a new and confident creative campaign in mid-June. This combined with a focus on building the brand's presence in bars and cafes saw Dunhill achieve market share growth nationally ... [consumer research showed]...increased consumer presence and relevance. ${ }^{\prime 31}$ BATA's report consistently attributed improvements in brand share to integrated marketing activities, including the launch of product innovations such as "King Size" cigarettes, small and soft packs, and "new creative campaigns". In other forums manufacturers have explicitly discussed the value of their guerrilla marketing. ${ }^{32}$

As early as the 1970s, manufacturers made careful plans to manage regulation by "establish[ing] unique images for leading brands and at the same time ensur[ing] that after above-the-line phase out, the advertising campaigns already built could be easily transferred to...other media". ${ }^{33}$ Many 
Australian industry documents, both pre- and post-TAP, frankly discussed the need to maximise the impact of remaining advertising opportunities, develop "instantly recognisable" brands, continue to research innovative new promotion techniques, and gradually adjust advertising strategies to acclimatise consumers before regulation was enforced. $^{34-37}$

\section{Transportable old brands instead of new brands}

The frequency of brand launches in Australia started to slow in the 1980s, due to frequent failure of new brands and competition pushing the price of brand launches to "astronomical levels". ${ }^{32-40}$ However, since the TAP Act, launching new brands has been seen as frankly wasteful. As one retail industry writer noted: "the ever tightening legislation has...put paid to a constant parade of new brands-it's difficult enough to promote existing "old favourites" without trying to launch something new without promotional opportunities... the companies have to be constantly creative with what they've got." ${ }^{\prime 41}$

The loss of ATL was seen as a terrible blow. RJR complained in 1997 that "the brand awareness goals set for a new brand or line extension that Australia used to reach in three to four months via print, billboard and direct marketing now take them two to three years to achieve. New brands have been almost impossible to launch." ${ }^{42}$ In preparation for this media desert, new brands were launched in the dying days of ATL in Australia in an attempt to create brand awareness before the market became darker, ${ }^{43} 44$ and RJR advocated this method in other markets in response to the Australian experience, recommending: "any propositions with merit should be launched while you still have full colour, $\mathrm{OOH}$, print \& direct marketing. The hell you put field sales through and the trade through will pale compared to the hell you face getting a new proposition to jell after the bans." 42

After the TAP Act, instead of launching new brands, manufacturers have enriched existing brand personalities and developed new variants within existing brand families, focusing on a small number of brands with pre-existing high awareness and strong campaigns where possible. ${ }^{45-47}$ The best example of this transportability is one of the best known Australian cigarette campaigns, fronted by actor Paul Hogan, an irreverent iconic Australian figure, in the 1970s. A series of bizarre mishaps, strange activities or unsolvable problems were tagged with Hogan's reassuringly good-humoured suggestion "Anyhow*...have a Winfield." Hogan was removed in 1980, but the format and slogan are still in use on pack outserts (cardboard wrappers placed around the pack) and in retail advertising 30 years later, helping to maintain Winfield in its number one position in the Australian market.

\section{The strategy}

The Australian dark market strategy appears to have been as follows. Before the restrictions were introduced, big powerful brands were selected, studied, and strengthened to ensure continued potency after the bans. In the lead up to the ban, spending on BTL was increased to prepare the consumer for the changed environment. ${ }^{48}$ After the restrictions, novelty was introduced within brand families through broader variant ranges (particularly in the supervalue and mainstream product categories) and product changes. Novel offerings included round-cornered packs and American style soft-packs for premium cigarettes; more modest pack changes (largely in graphic design) for mainstream and value cigarettes; and a new emphasis on mid-range (6-8 mg) tar banding, Australia's fastest growing tar segment. In addition, when 1999 taxation changes made it financially viable, brands which had traditionally only been available in large pack sizes diversified into small packs of 20 or $25.4^{49} 50$

These offers provide flexibility and novelty for consumers within a known brand offer, and make marketing expenditure more efficient for the manufacturer as the existing brand personality provides infrastructural support for the new offering. Loopholes in the legislation are also sought to continue brand images in the mind of the consumer by any available below-the-line means. Loopholes are extended as far as possible, denying the spirit of the law and sometimes complying with the letter only when forced, ${ }^{51}$ as Rothmans' head office noted regarding Australian POS advertising in 1997: "local tobacco companies tend to stretch meaning of regulations and only removed [advertising] after retail warning was issued." ${ }^{\prime 42}$ Cementing and sustaining a continuing personal relationship between the consumer and their brand is the priority. As PML argued in 1990: "going out and directly contacting our key target consumer is becoming increasingly more important, particularly in light of the upcoming media ban... we must now talk to the consumer face to face..." ${ }^{\prime 48}$

\section{BTL (and ATL) activities after the TAP Act}

After the restrictions were introduced, the manufacturers discussed a wide range of channels available to communicate with their consumers and promote their priority brands. In addition to the guerrilla marketing already discussed, these have included:
- advertising in imported international magazines
- altering the pack
- sponsorships
- brand stretching
- event promotions
- lifestyle premiums
- the development of corporate websites.

\section{International magazines}

Tobacco advertising is permitted in magazines that are both printed outside Australia and "not principally intended for distribution or use in Australia" and these have been targeted by the industry to gain a foothold. ${ }^{52-54}$

\section{Delivering novelty via the pack}

Manufacturers have printed on the inside of flip-top packs, printed on or changed the colour of the foil inside the pack, subtly changed pack design to provide novelty, and used pack and carton inserts and outserts-for example, to join two packs into a single "mini-carton" and display advertising imagery. $\dagger^{42}{ }^{55-57}$ Because of the importance of the pack, the industry fears the introduction of generic packaging. However they admit that generic packaging is only "a short step" from the placement of products under the counter in retail stores, and is possibly "achievable [in Australia] in the long term", particularly given the link to youth smoking. ${ }^{58}$

\section{Sponsorships}

The TAP Act currently permits "sponsorships of international significance", and the documents show that manufacturers see these sponsorships as vital to "consumer cut through"; select them for their brand synergy; and fund them both to market that brand via television and individual consumer attendance at the events and to provide opportunities to entertain VIPs. $^{34} 4851525759-63$

†Personal observation, Winfield 25s, NSW, 2002 
The importance of sponsorships is illustrated by an unusual exception to the "no new launches" rule: the recent launch of West by Imperial in Victoria, which houses the sponsorship exempted International Formula One competition. West was launched to coincide with the West/McLaren team winning the Victorian F1 in March 2003, underlining the synergistic power that the industry perceives international sponsorships to have in a dark market.

\section{Brand stretching}

Although the manufacturers repeatedly deny that trademark diversification promotes tobacco products, ${ }^{64}$ their stated intentions to use brand stretching, ${ }^{52636566}$ and RJR's statement that Australian manufacturers are "highly regretful that they did not move very early in the game to extend the reach of their trademarks well outside the tobacco category ...for constant reinforcement of brand positioning ${ }^{\prime 42}$ belies the claim.

\section{Event promotions}

Promotions, sampling, competitions, and sweepstakes via special theme nights at nightspots, pubs, and events and via mail and toll-free phone lines have been used, ${ }^{44} 5160656768$ designed to "get our product into the hands of opposition smokers in an involving way". " "Sell no tell" hostesses in branded costumes at nightspots have also been used. Because these models sell the product but do not talk about it, they are supposedly not engaging in "advertising". ${ }^{51}$

\section{Lifestyle premiums}

"Lifestyle" premiums such as diaries and entertainment guides were established as branded tools before TAP, and then continued after TAP in brand colours only, with the branding reinforced through POS displays. ${ }^{516567}$

\section{Corporate websites}

In March 2000, Eric Windholz, attorney with Philip Morris Corporate Services, wrote of PML's new corporate website: "as you are no doubt aware, our ability to communicate about the Company and its positions through traditional media is severely restricted. As a result, the website takes an added significance [sic]." ${ }^{\prime 69}$

\section{A case study: the resurrection of Peter Stuyvesant}

Imperial Tobacco entered the Australian market in 1999 and shortly afterwards appointed an agency to manage more than $\$ 10 \mathrm{~m}$ worth of BTL marketing activities. ${ }^{70}$ Peter Stuyvesant, an old and previously successful brand which sank into obscurity in the 1990s, is now being revived as Imperial's key premium small-soft-pack product, providing a good illustration of re-branding and growth in the absence of ATL. Sizeable risks have been taken to extend the brand's silver and blue retro styling, which is also reflected in the image based retail advertisements for the brand. Small silver and glass cabinets displaying only the Peter Stuyvesant soft pack range have been installed illegally in places such as cafes where cigarettes are not usually sold, minus the usual health warnings, allowing the brand a glamorous solo presence until detected by authorities. $\ddagger$ Arresting photographic advertising images on carton sides have been used to provide eye catching in-store displays, and special brand-blue plastic display modules have been provided to sit over the regular pack dispensers, highlighting the brand within the display unit and providing clear pack face display (fig l-3).§

Imperial has obtained the "exclusive right to sell cigarettes" (not the right to "sponsor") at popular music festivals, and the right has been exercised creatively with the assistance of Peer Group Media, a company specialising in youth marketing and headed by the editor of a local music magazine with impeccable street credibility. Imperial appear to be hoping for some memory of and resonance with the brand's old slogan "your passport to international smoking pleasure", which, if recalled, would offer camp retro irony for young Australians. Cigarettes have been sold by "air hostesses" in dedicated tents at festivals, along with clothes in suspiciously similar livery made by a separate company under a "Beaver Discovery World Air (DWA)" brand. ${ }^{71}$ One of

†Personal observation, NSW, 2002

§Personal observation, NSW, 2002

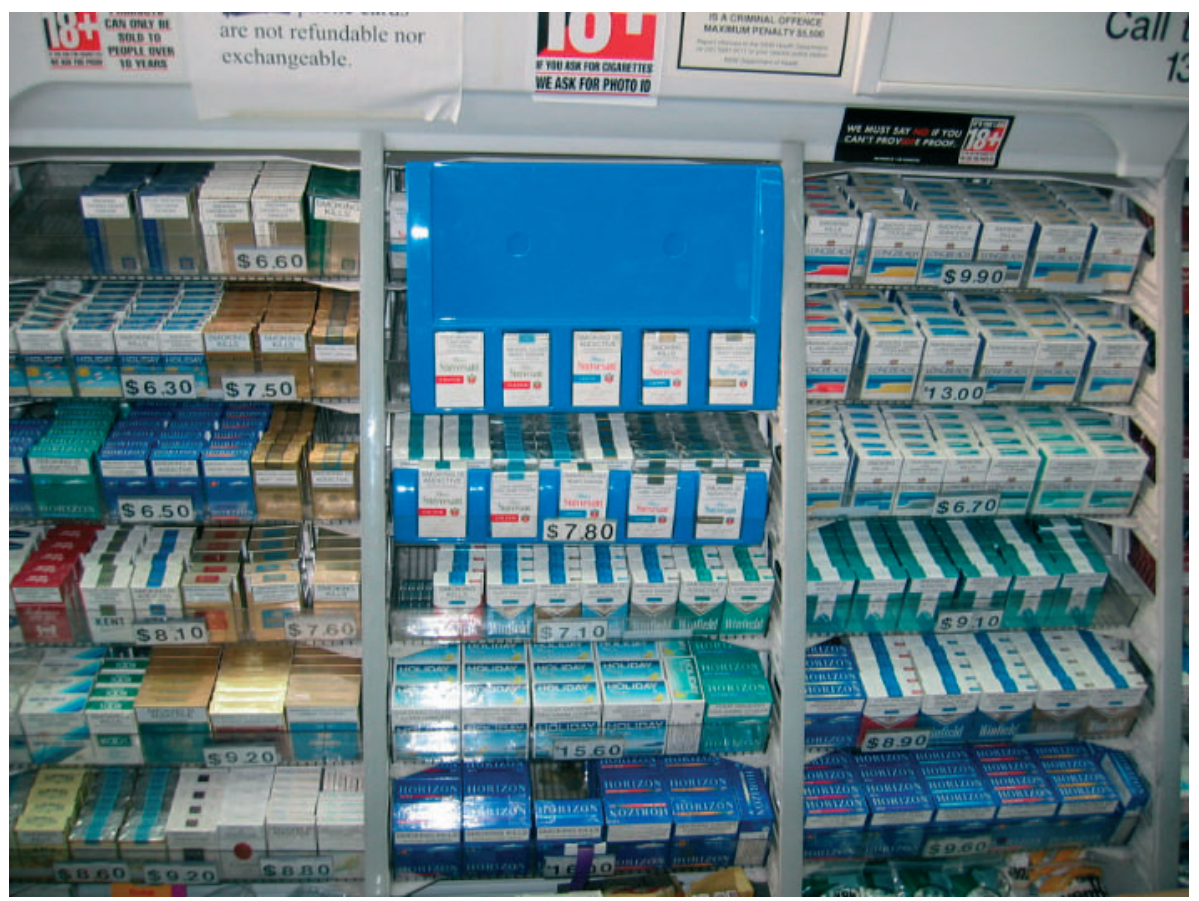

Figure 1 Custom-made blue plastic display to highlight the Peter Stuyvesant range within the existing display cabinet. 


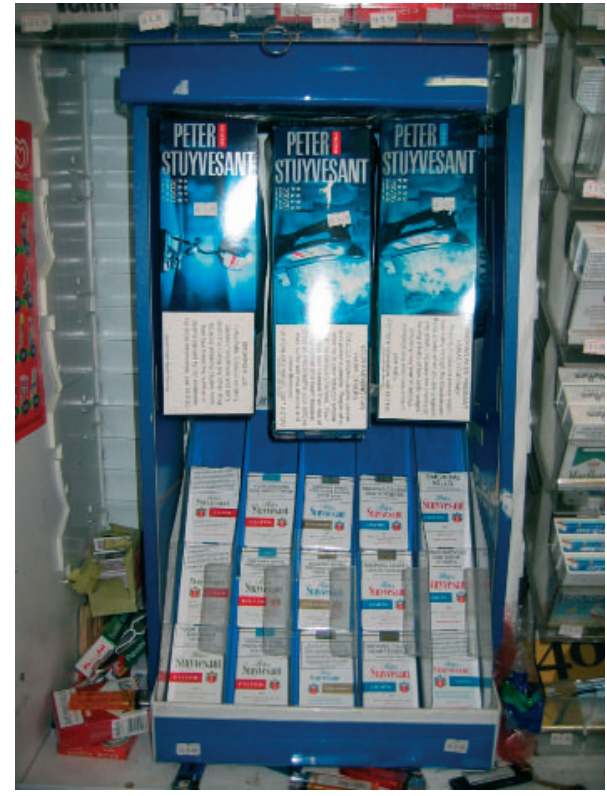

Figure 2 Stand-alone blue plastic Peter Stuyvesant display unit using carton sides to provide advertising imagery.

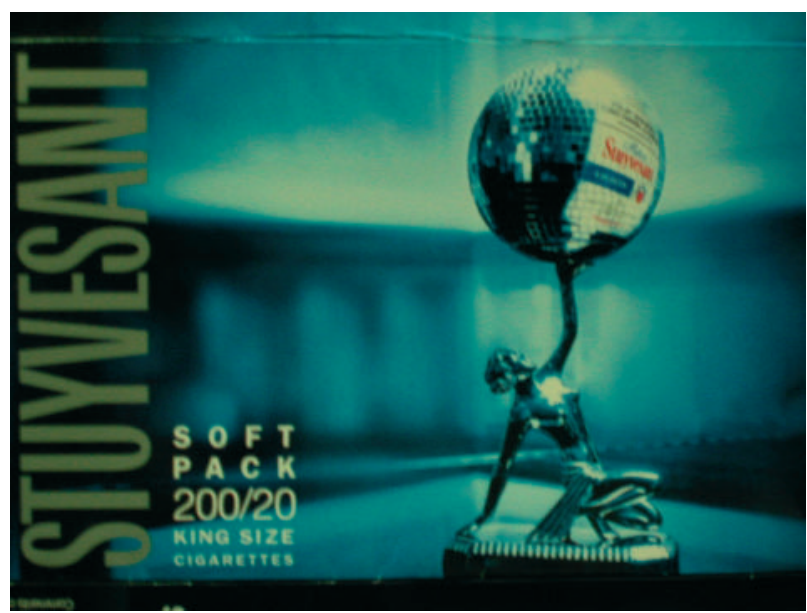

Figure 3 Detail of art on Peter Stuyvesant carton.

these festival appearances was linked to similarly retro-chic club nights, also under the DWA brand, promoted as a follow up to the festival. Invitations included a fictional back story for the company (fig 4), and a URL which led to a single webpage. The page's instruction "we'll have something special real soon, but for now, go look at porn" was linked to ironically un-sexy websites on subjects such as fly fishing and barn dancing (fig 5). A silver metal Peter Stuyvesant cigarette case, branded and perfectly sized to contain a soft pack and thus cover the health warning, has also been made available at music festivals.

Australian Convenience Store News observed in 2002: "Peter Stuyvesant's strength in the premium market is obscured in the aggregate market share data. Its share of the convenience store premium market increased from $11.6 \%$ to $13.2 \%$ last year... [it is] growing in the strongest segment, in particular the 20 s pack size."72 A review of AC Nielsen C*Track (convenience scanning) value share data from 2002 showed four Peter Stuyvesant products in the national top 40, and the total family ranked between sixth and 10th by state, with value shares from $2.0-6.6 \%$ of the state markets-no mean feat for a previously "uncool" brand..$^{73}$ Given that young smokers are fond of convenience stores, premium brands, and small packs it seems highly likely, given the marketing strategies, that at least some of this share growth has come from young smokers.

\section{CONCLUSIONS}

There are three main conclusions to be drawn from this material. Firstly, the industry acknowledges that marketing restrictions have an impact, validating their continued use in tobacco control. Secondly, the industry is extremely creative in circumventing these marketing restrictions, requiring tobacco marketing regulations to be informed by marketing expertise, regularly updated, and to adopt the broadest possible scope. Thirdly, tobacco control advocates, particularly those communicating with young people, could learn from the creativity of the tobacco industry.

Some may argue that brand choice is inconsequential to tobacco control and that manufacturers' ability to, in their words, "simply compete for brand share" is not the proper jurisdiction of tobacco control. However, this is belied by the enormous efforts expended by the industry on brand promotion, effectively an attempt to attract new smokers and keep existing smokers smoking. Brands and their transportability in a dark market are central concerns for the industry, and thus should be a central concern for tobacco control.

-A picture of this case is available at http://www.ashaust.org.au/pdfs/ StuyvTin02.pdf.

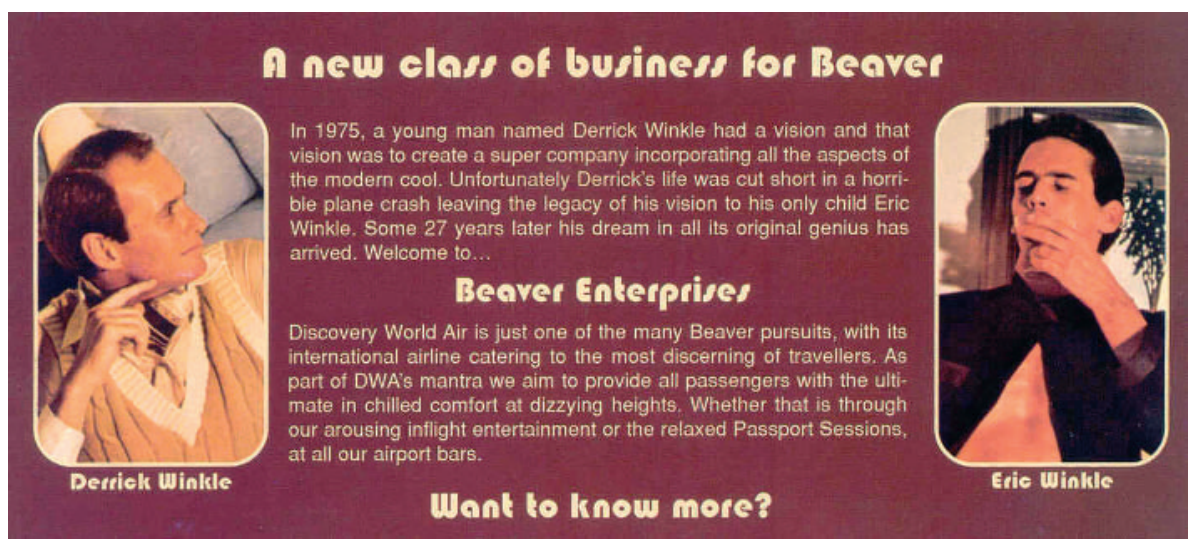

Figure 4 Part of an invitation to attend a series of music nights: fictional back story on the "Beaver DWA" company. 


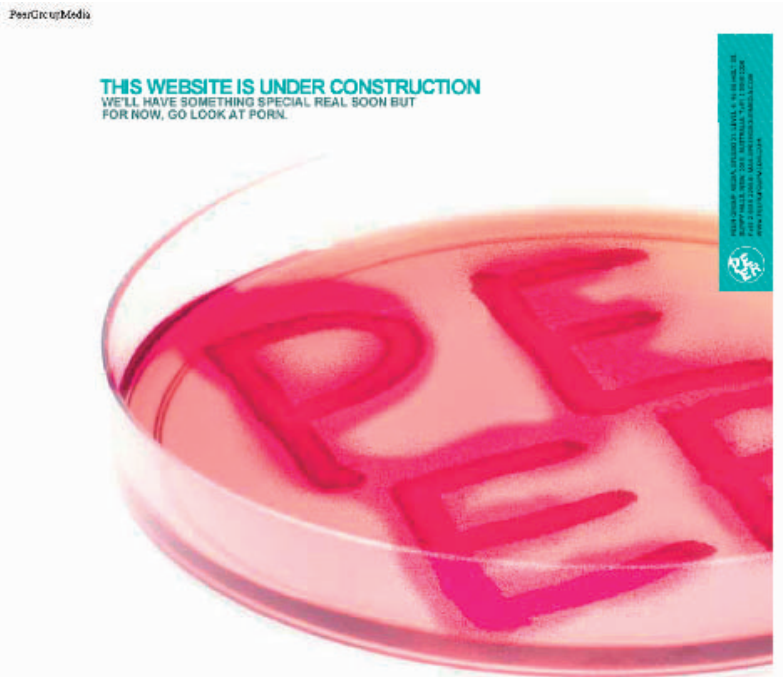

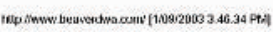

Figure 5 Beaver DWA webpage.

The industry clearly acknowledges that ATL advertising bans disrupt their business, making consumer awareness harder and more time consuming to achieve. However, even in a heavily restricted market, the cigarette industry keeps advertising. Despite the pain and reduced efficiency resulting from loss of ATL, BTL is stretched in innovative ways, and manufacturers breach the law until caught for short term benefits. Industry documents and observation suggest that the pack, POS, international sponsorships, and guerrilla marketing are the most important frontiers in a dark market. Advertising in imported international magazines, brand stretching, lifestyle premiums, and corporate websites also have a role to play.

The creativity of the industry in circumventing marketing restrictions highlights the need for truly comprehensive bans, addressing every aspect of all of these marketing activities. "Generic" packs, for example, would require complete standardisation: simply prohibiting current trademarks will not suffice. Inserts, outserts, foil, wrap, image, colour, typeface, printing on the cigarette rod, rod colour and tipping paper, and even scent would need to be considered (there is an Australian precedent for using scented foil for menthol cigarettes) as they are all means by which brand identity can be communicated. As discussed in other papers, ${ }^{2}$ a brand is far more than a visual trademark, and disruption of brand differentiation will require disruption of all aspects of brands, not just their name and logo.

Manufacturers prepare themselves and their consumers for onerous regulation years in advance, selecting, building, and transporting a strong set of existing brands into the regulated market. It follows that those contemplating regulation of tobacco marketing should closely guard proposals for marketing restrictions for as long as possible. Although this is inconsistent with usual due process, it could be argued that this industry has in fact relinquished its place at the

\section{What this paper adds}

Studies of cigarette marketing tend to focus on the effect of above-the-line strategies. There has been little published on the industry's strategies after above-the-line has been banned.

This paper describes the industry's overall strategy for dealing with the introduction of marketing restrictions, and the below-the-line marketing activities which have been integrated to promote cigarette brands after the introduction of bans.

negotiating table by deliberately and consistently flaunting the spirit of the law.

In a dark market, the industry creates novelty for the consumer not by launching new brands, but by making new offers within existing strong brand families. This increases the efficiency and effectiveness of their marketing activities by removing the arduous task of attempting to launch a completely new brand concept without ATL. The provision of a vast array of variants within a brand family not only creates consumer novelty, but provides critical mass in the retail display; if only one pack of each variant can be displayed by law, eight variants provide twice the visual space of four, increasing brand impact. Regulation of marketing should, if possible, incorporate limits on the type and number of offers that can be made within a brand group, and the grounds on which products can be differentiated, with a particular eye for the truth of manufacturers' product claims.

Australian cigarette manufacturers are not unique; they mirror trends in promotion of all kinds of products to young consumers worldwide, and tobacco control would benefit from studying other highly competitive youth markets (promoters of electronic/computer games and energy drinks seem particularly fond of guerrilla strategies, for example). Cutting edge, practising marketing experts could also be consulted on future directions and potential loopholes, and assist with the construction of both counter-marketing and legislation. As tobacco control is up against some of the most talented guerrilla marketing professionals in the world, it should, like them, avoid over-reliance on relatively static and expensive ATL strategies. Integrated marketing is likely to be more effective marketing, in tobacco control as much as any other endeavour.

The case study of the dark marketing of Peter Stuyvesant suggests some potential lessons for a tobacco control "brand". Create a strong brand identity and communicate it clearly. Ensure that every aspect of the consumer's experience of the brand is consistent with that identity. Integrate as many complementing marketing activities as possible to build your brand including BTL activities. Make your product stand out. Create a "world" for the product that the consumer will feel a part of, a world which complements the brand but is not necessarily "branded". Use humour, and let the consumer know that you know that they "get the jokes". Promote the brand in the consumers' own environment, particularly where they have fun. It is worth noting that the phenomenally successful "Truth" campaign in Florida, which raised awareness, changed attitudes, and lowered smoking prevalence among teens, followed all of these principles. ${ }^{74-77}$

If comprehensive tobacco marketing regulation can be combined with cutting edge integrated marketing of tobacco control, it may be possible to counter the industry's continuing efforts to attract and retain customers, even in a "dark" market. 


\section{ACKNOWLEDGEMENTS}

Thanks to Simon Chapman and reviewers for helpful comments and Fiona Byrne for indispensable information management. The research reported in this paper was supported by grants from the National Health and Medical Research Council (2001-2003 \#153857) and the US National Institutes of Health (2001-2005 \# R01 CA87110-01A1).

\section{REFERENCES}

1 Carter SM. New frontier, new power: the retail environment in Australia's dark market. Tobacco Control 2003; 12(suppl III):iii95-101.

2 Carter SM. The Australian cigarette brand as product, person and symbol. Tobacco Control 2003;12(suppl III):iii79-86.

3 Wakefield M, Morley CP, Horan JK, et al. The cigarette pack as image: new evidence from tobacco industry documents. Tobacco Control 2002; 1 1(Suppl I): i73-i80.

4 Wakefield M, Letcher T. My pack is cuter than your pack. Tobacco Control 2002;11:154-6.

5 Commonwealth of Australia. Tobacco Advertising Prohibition Act. Commonwealth Consolidated Acts, 1992. http://www.austlii.edu.au/au/ legis/cth/consol_act/tapa1992314/index.html (Accessed 14 Jul 2003).

6 Kotler P. Marketing, 4th ed. Sydney: Prentice Hall, 1998.

7 Glossary. Multimedia Marketing.Com, an affiliated company of London Metropolitan University \& Manchester Metropolitan University 2003. http:// multimediamarketing.com/treasurechest/glossary.asp (Accessed 29 Aug 2003).

8 Baker M. MacMillan dictionary of marketing and advertising, $1 \mathrm{st}$ ed. London: The MacMillan Press Ltd, 1984.

9 Anon. The international encyclopedia of marketing/European Marketing Confederation, 2nd ed. London: Butterworth-Heinemann, 1997.

10 Rosenberg J. Dictionary of marketing and advertising, 1st ed. New York: J. Wiley, 1995.

11 Bradmore D. Australian marketing dictionary, 1 st ed. Hampton, Victoria: MacStyle, 1990.

12 Marketing glossary, Chartered Institute of Marketing website. The Chartered Institute of Marketing 2003. http://www.cim.co.uk/cim/ser/html/ infQuiGlo.cfm?letter = A (Accessed 29 Aug 2003)

13 Rossiter JR, Percy L. Advertising communications and promotions management, 2nd ed. Boston, Massachusetts: Irwin/McGraw-Hill, 1997.

14 Media Watch. Advertising gets integrated. Media Watch 2002. Last updated: 2 Sep 2002. http://www.abc.net.au/mediawatch/stories/ (Accessed 1 Oct 2002).

15 British American Tobacco Australasia. The Challenge of Change [CD ROM]. Sydney: British American Tobacco Australasia, 2001

16 Orlando Conference: summary of BATCo participants' comments 19 Feb 1992. British American Tobacco. Bates No. 502585153/5154. http:// tobaccodocuments.org/guildford_misc/502585141-5192.html (Accessed 24 Jun 2003).

17 Rushkoff D. Coercion: the persuasion professionals and why we listen to what they say, 1st ed. London: Little, Brown \& Company, 2000.

18 Byrnes H. Fashion's smoking gun: top designers' functions sponsored by cigarette company. Sun-Herald (Sydney, NSW) 11 Aug 2002:3.

19 Harper T. Marketing life after advertising bans. Tobacco Control 2001;10:196-7.

20 Carter S. Worshiping at the Alpine Altar: promoting tobacco in a world without advertising. Tobacco Control 2001;10:391-3.

21 Malone RE, Balbach ED. Tobacco industry documents: treasure trove or quagmire? Tobacco Control 2000;9:334-8.

22 Tobacco manufacturers' document websites. http://www.pmdocs.com-bin/ rsasearch.asp; http://www.bw.aalatg.com/public.asp; http:// www.lorillarddocs.com/cgi-bin/rsasearch.asp; http://www.rjirtocs.com/ rirtdocs/index.wmt?tab = home

23 Council for Tobacco Research, document website. http://www.ctr-usa.org/ $\mathrm{ctr} /$ index. wmt? tab = home

24 Tobacco Institute, document website. http://www.tobaccoinstitute.com/cgibin/Rsasearch.asp

25 Tobacco Documents Online. Smokescreen Corporation. http:// tobaccodocuments.org/

26 Canadian Council for Tobacco Control tobacco documents site. http:// www.ncth.ca/Guildford.nsf

27 British Columbia Ministry of Health Services tobacco documents site. hittp:// www.moh.hnet.bc.ca/cgi-bin/guildford_search.cgi

28 Center for Disease Control and Prevention Guildford tobacco documents site. http://www.cdc.gov/tobacco/industrydocs/index.htm

29 Chapman S, Byrne F, Carter SM. "Australia is one of the darkest markets in the world": the global importance of Australian tobacco control. Tobacco Control 2003;12(suppl III):iii 1-3.

30 Philip Morris Limited. Project Dagger launch plan. $26 \mathrm{Jul}$ 1990. Philip Morris. Bates No. 2504077083/7094. http://legacy.library.ucsf.edu/tid/ qpi29e00

31 British American Tobacco Australasia. Annual report. Sydney: British American Tobacco Australasia, 2000.

32 Anon. Marketing survival in the trenches. B \& T marketing \& media 1983;Aug 26:18.

33 Cullman H. Philip Morris International five year plan, 1975-1979. Jul 1974. Philip Morris. Bates No. 2048148837/8989. http://legacy.library.ucsf.edu/ tid/izs81f00
34 Philip Morris International. Philip Morris Asia/Pacific three year plan, 19921994. Dec 1991. Philip Morris. Bates No. 2500064000/4226. http:// legacy.library.ucsf.edu/tid/wwi19e00

35 Bramley B. [Importance of quality on brand goodwill: presentation delivered at the BAT Marketing Conference, November 19-23, 1991]. 20 Nov 1991. British American Tobacco. Bates No. 202235487/5533. http:// tobaccodocuments.org/health_canada/20223548.html (Accessed 24 Jun 2003).

36 Philip Morris. [Presentation notes-slides 69-79 Australian retail market: notes for a NY Marketing Meeting]. 1992. Philip Morris. Bates No. 2504107193/7197. http://legacy.library.ucsf.edu/tid/vwn32e00

37 Philip Morris (Australia) Limited. Superlights 30's. 18 Nov 1987. Philip Morris. Bates No. 2500113068/3074. http://legacy.library.ucsf.edu/tid/ ¡ll19e00

38 RJ Reynolds Tobacco International. Australia 1981 operating plan. Sep 1980. R.J. Reynolds. Bates No. 505525649/5653. http:// legacy.library.ucsf.edu/tid/kol15d00

39 Altizer C, Bolanowski G, Christopher R, Goodwin C. Ventilation seminar. May 1983. Philip Morris. Bates No. 2057251669/1968. http:// legacy.library.ucsf.edu/tid/acq52e00

40 Shoebridge N. Australia: ten years of advertising. Oct 1985. Lorillard. Bates No. 83609386/9387. http://legacy.library.ucsf.edu/tid/jfl09c00

41 Swanton L. Tighter laws drive cigarette company creativity. Australian Service Station and Convenience Store News 1998;May/Jun:38-9.

42 Stockdale B. Australia trip: topline learning (highly restricted market). 12 Feb 1997. R.J. Reynolds. Bates No. 518093846/3852. http:// legacy.library.ucsf.edu/tid/ads90d00

43 Philip Morris. Minutes from Tuesday, June 19 presentations "New Products". 19 Jun 1990. Philip Morris. Bates No. 2500114149/4156. http:// legacy.library.ucsf.edu/tid/dgl19e00

44 Daily Telegraph Mirror. (Sydney, NSW). Cig groups make light of ad bans. 22 Nov 1990. Tobacco Institute. Bates No. TIMN0377798. http:// legacy.library.ucsf.edu/tid/say $42 f 00$

45 Philip Morris International. PMI marketing meeting minutes. 17 Jun 1991. Philip Morris. Bates No. 2504107222/7265. http://legacy.library.ucsf.edu/ tid/kii29e00

46 Yann Campbell Hoare Wheeler. W.D. \& H.O. Wills Packaging Research Study: qualitative report. Nov 1994. British American Tobacco. Bates No. 500245336/5406. http://tobacco.health.usyd.edu.au/tds/ BAT500245336_5406 (Accessed 10 Jul 2003).

47 Philip Morris. Positioning paper-Project Alpha. 6 Jun 1991. Philip Morris. Bates No. 2504107057/7061. http://legacy.library.ucsf.edu/tid/cii29e00.

48 Philip Morris. 1991 original budget: Marketing Presentation. 3 October 1990. 1990 Oct. Philip Morris. Bates No. 2504107139A/7171. http:// legacy.library.ucsf.edu/tid/aii29e00

49 Carter S, Younie S, Scollo M. Sustaining the country, protecting the poor: the Australian tobacco industry and economic policy 1970-2000. Tobacco Control 2003; 12(suppl III), IN THIS ISSUE.

50 Anon. Tobacco category review. Retail World 2001;54(Nov 26-Dec 7): 11-13.

51 Zufic D. [Forms part of a fax from Denis Zufic to Robert Sarmento on the topic of government restrictions that impede the Australian Tobacco Industry]. 16 Aug 1995. Philip Morris. Bates No. 2071284487/4490. http:// legacy.library.ucsf.edu/tid/nkq08d00

52 British American Tobacco. [Extract from BATCo 1992-1996 company plan]. 1991. British American Tobacco. Bates No. 502585324/5329. http://tobaccodocuments.org/b__moh/11376.html (Accessed $10 \mathrm{Jul}$ 2003)

53 Leo Burnett. Philip Morris International 1980 media plan. 20 Sep 1979. Philip Morris. Bates No. 2500000014/0079. http://legacy.library.ucsf.edu/tid/ igz09e00

54 Zenith Media Worldwide. Project Talisman media implications. 9 Jul 1993. British American Tobacco. Bates No. 503074509/4515. http:// tobaccodocuments.org/health_canada/2126_01.pdf (Accessed $10 \mathrm{Jul}$ 2003).

55 Vincent S. Australian Marlboro Outsert-Marlboro Filter \& Lights 25s Europack. 4 May 2000. Philip Morris. Bates No. 2078450631. http:// legacy.library.ucsf.edu/tid/aim70c00

56 Graebner C. Australian Marlboro Outsert-Marlboro Filter \& Lights 25s Europack. 4 May 2000. Philip Morris. Bates No. 2078450632. http:// legacy.library.ucsf.edu/tid/zhm70c00

57 Goldberg H. 1994 second revised forecast presentation, June 1994, New York. May 1994. Philip Morris. Bates No. 2504204001/4063. http:// legacy.library.ucsf.edu/tid/ygn32e00

58 Philip Morris (Australia) Limited. Anti smoking agenda. 1998. Philip Morris. Bates No. 2072523055/3075. http:// legacy.library.ucsf.edu/tid/lab06c00

59 Philip Morris International. F-1 and bikes evaluation-Australia. 14 May 1993. Philip Morris. Bates No. 2504052867/2870. http:// legacy, library.ucsf.edu/tid/fyw32e00

60 Barber K, Sharrock S. Morgan consumer review, April-June 1994. Aug 1994. Philip Morris. Bates No. 2504103801/3908. http:// legacy.library.ucsf.edu/tid/jio32e00

61 Bible G. Australia [Memo to D. Davies]. 3 Mar 1993. Philip Morris. Bates No. 2047896065A/6071. http://legacy.library.ucsf.edu/tid/bzo07e00

62 Oostrom D. B\&H creatives. 27 Oct 1994. British American Tobacco. Bates No. 500245465/5469. http://tobaccodocuments.org/guildford_misc/ 500245450-5479.html (Accessed 23 Jun 2003).

63 British American Tobacco. [BATCo company plan report excerpt]. [1991]. British American Tobacco. Bates No. 502630615/0641. http:// 
tobaccodocuments.org/health_canada/2250 01.html (Accessed 14 Jul 2003).

64 Trademark diversification. 30 Oct 1992. Philip Morris. Bates No. 2504099390/9395. http://legacy.library.ucsf.edu/tid/xtu43e00

65 Philip Morris. Minutes from Thursday, June 21 presentations "Marketing restrictions". 21 Jun 1990. Philip Morris. Bates No. $2500114168 / 4176$. http://legacy.library.ucsf.edu/tid/zgd42e00

66 McCrossin M. Clayton Utz. [Fax to R. Goldbrenner, Lorillard]. 2 Aug 1993 Lorillard. Bates No. 83664587/4588. http://legacy.library.ucsf.edu/tid/ gtc $44 \mathrm{c} 00$

67 Philip Morris. [Presentation notes - slides 1-73 Australian retail market: notes for a NY Marketing Meeting]. 1992. Philip Morris. Bates No. 2504107172A/ 7192. http://legacy.library.ucsf.edu/tid/dii29e00

68 Philip Morris. [Presentation notes: slides 1-68 "Australian New Products"]. 1992 Jul. Philip Morris. Bates No. 2504107198/7218. http:// legacy.library.ucsf.edu/tid/wwn32e00

69 Windholz E. Australian website-status report. 30 Mar 2000. Philip Morris. Bates No. 2072557317A/7318. http://legacy.library.ucsf.edu/tid/ giz95c00
70 Madjarian A. 2000: The year that sizzled. B\&T 2001. http://bandt.com.au/ articles/78/0c003378.asp (Accessed 4 Oct 2002).

71 Hornery A, Moses A. Cig day out. Sydney Morning Herald (Sydney, NSW) 29 Jan 2003:20

72 Anon. Focus stock selection within tightening regulations. Convenience Store News 2002;(Mar/Apr): 18-21.

73 Anon. Tobacco regulation review. Australian Convenience Store News 2003; (Jan/Feb):30

74 Hicks J. The strategy behind Florida's "truth" campaign. Tobacco Control 2001;10:3-5.

75 Zucker D, Hopkins R, Sly D, et al. Florida's "Truth" campaign: a counter marketing, anti-tobacco media campaign. Journal of Public Health Management and Practice 2000;6:1-6.

76 Sly D, Heald G, Ray S. The Florida "Truth" anti-tobacco media evaluation: design, first year results, and implications for planning future state media evaluations. Tobacco Control 2001;10:9-15.

77 Sly D, Hopkins R, Trapido E, et al. Influence of a counteradvertising media campaign on initiation of smoking: the Florida "Truth" campaign. Am J Public Health 2001;91:233-8. 